給することになっている。

火発電形は外部の電源とは速絡がないから消費動 力の急变に刘応するようになっており, 䄪 $20 \%$ \%位の 堌減は可能でる。平常状態に復㷌与るに要与す时問 は全部燃业機系統の情勢によるものである。

\section{運 転 成 績}

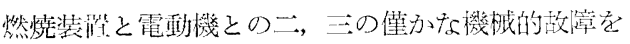

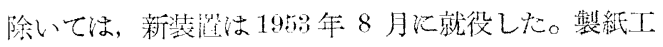

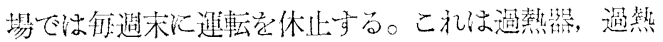
蒸父管, 蒸気草, タービン等の高温度下で操策してい る部品のストレッス学綬和するためで岁る。

本工場では，凝縮水系汇法化学蒋品学添加しない。 処理された井下水はエバポレータに給水される。多少 アンモニヤの痕跡を含んでいるが高生部に導入され， $16^{\circ} \mathrm{C}$ に和いて ph 倪は平均 9 である。給水の試料を 調查すると高生給水中の残椬は毎リットル当り単に

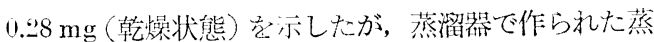
溜水中には $0.57 \mathrm{mg}$ あった。汽水分離器で同時に測 定したが，4偣乃至与倍の集中率を示し，特に硅酸の 分離は工学的佂面い絽果でめった。結局 $140 \mathrm{~kg} / \mathrm{cm}^{2}$

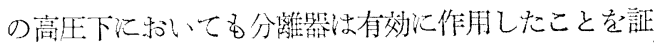
明した。

単管式ポイラの公式試験において, 平常状態では保

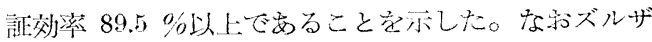

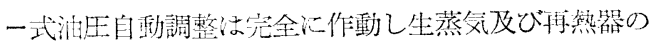
蒸领温度は注とんど一定不变であった。

結諭として，Velsenにおける装置は，超高生の採 用により産業汽鑵として子経济的価值が著るしく上界 した実例学示するのであって将米，本邦の製紙工場に

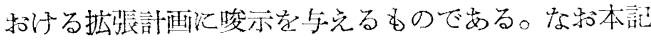
事は抄訳であるから，詳細は Boiler House Review 1957 年1月号を参照せられんこと学希㕵する。

\title{
ドナウ河三角洲の産業：アシを原料 とするパルプ
}

東プロック五力国が Bralia（ルーマニヤ）にアシを 加工するコンビナートを設立する予定である。

チェコスロバキヤ，ポーランド，ソヴィエト，及び 東ドイッの援助の下に，ルーマニアはドナウデルタの 巨大なアシの野林を経済的に十分利用するべく着手し ている。Braliaの近くにコンビナートを設立する尒定 で, これはアシを，パルプを始め各種の材料に加工す ることになっている。ルーマニヤの研究場の準借工作

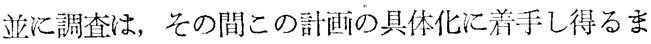
で進捗している。この冬，原料のアシのコンビナー トへの摩擦祭き供給を確保するべく, 各種の型の朾入 機によるアシの収穫の広沉な実験が企てられた。

既溇十年前から，ドナウデルタの広いアシの広野 の経渻的利用を目ざす計两があり，就中製紙が最も間 題となった。そのための原料の給源は殆んど徂尽蔵で ある。とにかく、約 $3,000 \mathrm{~km}^{2}$ に達するデルタ面程 のン/3以上が，高さ $3 \mathrm{~m}$ のアシで蔽われているのであ る。ドナウ河は Tulcea の北力約 $7 \mathrm{~km}^{2}$ の地点で, 偉大なる河口の支流に分れ, これは支流, 潟, 沼沢, 湿地等が縦横に交わる地带る包囲している。ここには 淮鳥水鳥の群が発生し，以前は然数の狼や水片が俳䧃 した。陸地にわずかに住居が見られ, 主として漁夫が
その生計を立てている。ドナウ河口の最も外側の支流 は黑海湖岸と $96 \mathrm{~km}$ 離孔ている。最北の支流 Kilia 川 は $111 \mathrm{~km}$ 以上に及び水量も最も豊富であるが, 以前 はあまりにも分岐しているため, 航行には最る不利な 川であった。その河口には㳂い浅瀬がある。しかし多 くの情報は，この支流がソヴィエトによって改築され たことを伝えている。ヨーロッパドナウ委員会は1858 年, 真中の支流一Julian川一の利水作策をもって始ま り，これを航行運河に完成した。その幅は $100 〜 130$ $\mathrm{m}$ の間学変動し，長さは $82 \mathrm{~km}$ である。二っの巨大な 防波堤が航行路学海から保護している。最南の支流は 長さ $96 \mathrm{~km}$ で, 深さは平均 $10 \mathrm{~m}$ である。しかしその 河口に砂州があり，航行を遮断している。

1856 年パリの講和でヨーロッパドナウ委員会が Isaccea までの，1883 年には Bralia までのドナウ潟 に対する国際的機関として設置された。1988年, 委員 会の権限は Sinaia の協定により, ルーマニヤに有利 なよ5に大幅に制限された。Bralia から Ulm までの 区間に対しては，1921年7月23日のドナウ河航条例に。 基づき国祭ドナウ委員会がウイーンに侴設されたが， これは 1940 年解散した。新協定が 1949 年ベルグラー

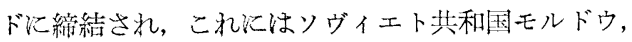


ウクライナ，並にルーマニヤ，ブルガリヤ， ハンガリ 一、ユーゴスラヴィヤ及びオーストリヤの諸国が加入 した。この委員会恃全ドナウ河を管轄するものであり, ドナウ潟及び鉄門に対する特別打を保持している。最 近, 更に Sofia の常設のドナウ委員会について述べら れて拈り，これは全東ヨーロッパ諸国が連合している

“経済相互扶助会議”の一組織である。この委員会の 設立には，ドナウ河の制水権を得ようとするソヴィエ ト並びにニーゴスラヴィヤの努力が反呋している。

第二次大戦後, 東ブロック諸目がその国民経済の拉 大におもむいた時, ドナウのアシの利用計画が再び復 活した。既にルーマニヤは数年前, 試験場を設立し, アシの刚入れと加工を試験している。予備工作は本年 2 月までに, ブカレストに一会議を召集する程に進捗 し, この会議には, ルーマニヤ, ポーランド, チェコ スロヴァキヤ及び DDR の代表者が会合し，一決議書 の署名をもって終結した。それ机よると，諸国はドナ ウデルタからのアシを加工するため一大コンビナート を Braliaに建設することに協力することに同意した。 マアシの収穫の確保に対し参加諸国の共同作業を高め ること, 水陸の作業の機械化に対し, 収穫現場に曹門 家を派遣することを決議した。

まず最切に計画されたのは，一大パルプ工場の設立 であり，その生産高は1960 年には圳に 10 万トンに達
するという。更にビスコース, 濃縮飼料, アルコール, 糖類，建築枋料及び煉炭の生産が考虑されている。既 に試験場の建物はアシとセメントで造られている。ブ カレストの協定ではパルプ製造の際の廃物の利用の間 題が取披われ，アシの廃物から製造し得た一連の新ら しい建築材料が試験された。パルプ工場の設立と平行 して, 廃物加工の工場を建設し得るよ5, 更に研究す ることが推奨された。

ドナウデルタの研究所は又, アシ野林にいる害虫の 駆除及び取入れを確保すべき効力ある機械につい二関 与している。収穫機械と水陸雨用装甲自動車を結合し たすのが発明され，これは空父を淽たしたフロートを 越えてまわる無限軌道を具觉, 陸上, 水中, 又沼沢地 等でも動くことが出来る。これを利用して，1 日に50 トンまでのアシが欷られるはずである。刚り取られた アシは水路及びヶーブル鉄道によって工場に運び込ま れる。

過ぎし冬，チエコスロヴァキヤの専門家も実験に参 加した。その時には，工業用水生植物刚入機“Esox” 及び発動機付杊入機 “Robot”が試験された。この計 画に関与する国々の接触は今後も続けられる筈であり， 近い内に再協定が文期されている。（ヴォッヘンブラ ット誌より——協会香川抄訳）

\section{“Egan's” エヤー・ナイフ・コーター}

(表紙写真解説)

エヤー・ナイフ・コーターは, 米国では主に印刷用 紙や厚紙へのクレー・コーテングに盛ん利用されて おりり一度仕上った紙ロールを用いてコーテングする 場合と裴紙の行程中に応用する場合とがある。後者は 多 $<$ fourdrinier board や white patent coated cylinder board 等のブリーチド・クラフトに限られる。

本図は土ヤー・ナイフ・コーターの原理図でロ一 ル・コートされた後, エヤー・ナイフで余分のコーテ ングを吹きとばすと共にコーテング表面を平滑にする。 コーテング量はこのエヤー・ナイフ・スロットの取付 角, 幅及び送風圧によって決まる。コーテング速度は 乾燥炉の能力次第で最高 1,000 呎/分まで可能である。

Egan のエヤー・ナイフ・コーターは, エヤー・ナ イフ自体のデザインは勿論のこと, キャッチ・パンの 構造にも特澺を払い，その高性能は既に定評あると

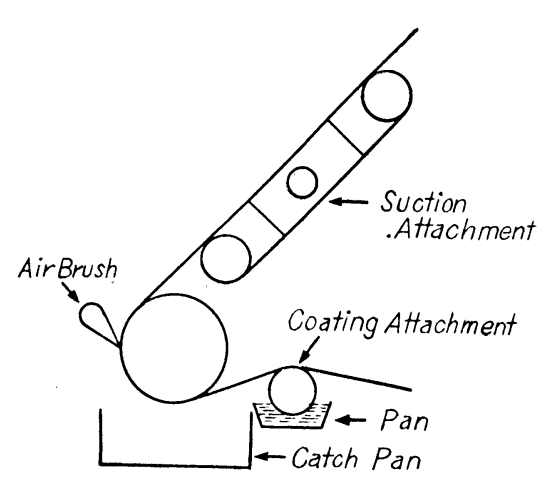

ころで, 米国では将来ブラッシュ・コーターの分野へ も進出するであろう, と期待されている。 